\title{
MISI EMANSIPATORIS \\ PENYELENGGARAAN PENDIDIKAN ISLAM
}

\author{
Indah Aminatuz Zuhriyah \\ Dosen Tetap Jurusan PGMI Fakultas Tarbiyah UIN Maulana Malik Ibrahim
}

\begin{abstract}
Abstrak
In facing the complexity of life, the process and the education system are not free from some problems such as political problem, economic problem social problem, cultural problem, and religious problem. The choices of functions which are given priority depend on the outcome of the interaction process and the education system with its environment. Facing the reality, the important thing to notice is to restore the initial orientation of the Islamic education itself, namely by providing emancipatory liberation or a mission for every human being. So with the education, people are able to realize the ideal of the Islamic education namely being a man of Muslim plenary.
\end{abstract}

Keywords: Islamic education, emancipator

\section{A. Pendahuluan}

Pendidikan merupakan sebuah proses dan sekaligus sistem yang bermuara pada pencapaian tujuan tertentu yang dinilai dan diyakini sebagai yang paling ideal. Bagi bangsa Indonesia tujuan ideal yang hendak dicapai lewat proses dan sistem pendidikan nasional ialah sebagaimana yang telah dituangkan dalan UUSPN No. 20 Tahun 2003 Bab II Pasal 3:

"Pendidikan nasional berfungsi mengembangkan kemampuan dan membentuk watak serta peradaban bangsa yang bermartabat dalam rangka mencerdaskan kehidupan bangsa, bertujuan untuk berkembangnya potensi peserta didik agar menjadi manusia yang beriman dan bertakwa kepada Tuhan Yang Maha Esa, berakhlak mulia, sehat, berilmu, cakap, kreatif, mandiri, dan menjadi warga negara yang demokratis serta bertanggungjawab"

Berdasarkanhal tersebut, menurut Fadjar (1995:51-52) pendidikan 


\section{Indah Aminatuz Zuhriyah - Misi Emansipatoris ...}

Islam di Indonesia sebagai sub-sistem dari sistem pendidikan nasional yang mencita-citakan pada terbentuknya insan kamil atau muslim paripurna, secara implisit akan mencerminkan ciri-ciri kualitas manusia indonesia seutuhnya sebagaimana yang digambarkan di atas. Tentu saja apa yang digambarkan sebagai yang ideal itu masih dalam pengertian abstrak umum. Untuk pengertian praktik pendidikan harus dilakukan subtansiasi, sehingga yang abstrak umum itu menjadi operasional. Dalam bahasa pendidikan dikatakan harus ada taksonomi dan usaha ini tidak dapat dilakukan sekaligus, karena taksonomi itu menyangkut sudut pandang. Bagi dunia pendidikan - lebih-lebih pendidikan Islam - hal ini tidak sederhana dan penuh problematik.

Lebih jauh lagi, dalam menghadapi tata kehidupan yang semakin kompleks, proses dan sistem pendidikan tidak terbebas dari persoalanpersoalan seperti politik, ekonomi, sosial, budaya, dan agama. Pilihanpilihan fungsi mana yang mendapat prioritas, tergantung pada hasil interaksi proses dan sistem pendidikan dengan lingkungannya.

Bertolak dari uraian di atas, maka masalah mendasar yang muncul ialahbagaimana orientasilembaga-lembaga pendidikanIslamyangada sekarang ini, baik berbentuk pondok pesantren, madrasah, maupun sekolah dan perguruan tinggi. Secara jujur harus diakui bahwa apa yang selama ini menjadicita-cita ideallembaga pendidikan Islam masih sangat abstrak umum. Akibatnya, yang muncul (operasionalnya) juga kurang mencerminkan kejelasan atau bahkan nampak 'semu'. Dilihat dari segi jumlahnya (secara kelembagaan) cukup besar. Di Jawa Timur saja, berapa jumlah pondok pesantren, madrasah, maupun sekolah dan perguruan tinggi yang dikelola oleh umat Islam (baik ormasnya maupun oleh perorangannya). Namun, kalau dilihat dan dinilai dari sisi mutu maupun peran yang bisa diharapkan bagi pengembangan kualitas manusia, barangkali masih minim. Lebih-lebih jika dikaitkan dengan kerangka global, atau dengan apa yang sering disebut era informasi dan industrialisasi.

Untuk menyelesaikan masalah-masalah yang dihadapi oleh dunia pendidikan Islam sebagaimana yang digambarkan di atas, maka perlu ada keterbukaan wawasan dan keberanian dalam menyelesaikan masalah-masalahnya secara mendasar serta menyeluruh. Hal-hal yang mendasar itu menurut Fadjar (1995: 53) antara lain: 1) kejelasan antara cita-cita dengan langkah operasionalnya, 2) penguatan di bi- 
dang sistem kelembagaannya, dan 3) pembaharuan dalam sistem manajemennya.

Berdasarkan penjelasan di atas, yang penting diperhatikan adalah mengembalikan orientasi awal dari pada pendidikan Islam itu sendiri yakni dengan memberikan pembebasan atau membawa misi emansipatoris bagi setiap manusia. Sehingga dengan pendidikan tersebut, manusia mampu merealisasikan cita-cita luhur pendidikan Islam yaitu menjadi manusia muslim paripurna. Untuk itu, dalam makalah ini akan dibahas secara detail mengenai misi emansipatoris dalam pendidikan Islam.

\section{B. Manusia Dalam Perspektif Pendidikan Islam}

Pemikiran tentang hakikat manusia dibahas dalam filsafat manusia. Pencarian makna diri akan siapa sebenarnya manusia sebenarnya telah lama berlangsung, namun sampai sekarang pun tidak ada kesatuan dan kesepakatan pendangan teori dan aliran pemikiran mengenai manusia ini. Kadang kala studi tentang manusia pun tidak utuh karena sudut pandangnya yang berbeda-beda. Pemahaman yang tidak utuh tentang manusia dapat berakibat fatal bagi perlakuan seseorang terhadap sesamanya.

Islam secara tegas mengatakan bahwa manusia adalah makhluk yang diciptakan oleh Allah, dapat dididik dan mendidik (homo educabile), hamba Allah ('abd Allah) yang mulia, berfungsi sebagai pemimpin atau pengelola bumi (khalifah fi al-ardl), dan terlahir dalam keadaan suci atau memiliki kecenderungan menerima agama (Islam) atau fithrah (Assegaf, 2004: 204). Lebih lanjut, ia memaparkan tematema penting dalam Islam dalam memandang manusia sebagaimana di bawah ini.

Pertama, manusia sebagai makhluk Allah. Ayat-ayat al-Qur'an menyebutkan bahwa manusia adalah makhluk yang diciptakan oleh Allah dari tanah, kemudian berkembangbiak melalui sperma dan ovum dalam suatu ikatan pernikahan yang suci serta produktifbiologis manusia. Dalam konteks ini Nabi SAW. bersabda:

"Bahwasanya seseorang kamu dihimpunkan kejadiannya didalam perut ibu selama 40 hari, kemudian berupa segumpal darah seperti itu pula lamanya, kemudian berupa 
segumpal daging seperti itu pula lamanya. Kemudian Allah mengutus seorang malaikat, maka diperintahkan kepada malaikat: engkau tuliskan amalnya, rejekinya, ajalnya, dan celaka atau bahagianya. Kemudian ditiupkanlah ruh kepada makhluk tersebut".

Kesadaran bahwa manusia hidup di dunia sebagai makhluk ciptaan Allah dapat menumbuhkan sikap andap asor dan mawas diri bahwa dirinya bukanlah Tuhan. Oleh sebab itu, manusia semestinya memandang manusia lain sebagai sesama makhluk ciptaan, dan tidak ada perhambaan di atntara manusia. Jadi, seorang istri tidak menghamba pada suami, seorang pegawai tidak pula menghamba pada pengusaha dan seorang rakyat tidak menghamba pada pemerintah. Yang patut menerima perhambaan dari manusia tak lain adalah Allah. Bahkan, Allah tidak meciptakan manusia selain untuk menghamba atau beribadah kepada-Nya. Dan, segala yang ada di langit dan bumi, sesungguhnya pun berserah diri kepada Allah. Dengan demikian, maka tidak berlaku konsep manusia sebagai homo homoni lupus atau manusia sebagai pemangsa bagi yang lain sebab tiada keistimewaan antara satu manusia dengan manusia yang lain kecuali karena taqwanya kepada Allah. Pergulatan eksistensi manusia pun bukan untuk menjadi yang terkuat, melainkan untuk menjadi yang paling bijak.

Kedua, manusia sebagai makhluk yang dapat mendidik dan dididik (homo educabile). Pada dimensi ini manusia berpotensi sebagai objek dan subjek pengembangan diri. Oleh karena potensi manusia tidak bisa berkembang tanpa rangsangan dari luar, seperti pendidikan misalnya, maka pendidikan pun harus berpijak pada potensi manusia tersebut. Makna penting dari penekanan pada potensi manusia ini berarti memandang manusia sebagai makhluk yang berpikir, memiliki kebebasan memilih, sadar diri, memiliki norma dan berkebudayaan. Implikasi dari hakikat dan wujud manusia sebagai homo educabile adalah sebagai berikut:

1. Pendidikan lebih bersifat menyediakan stimulus agar peserta didik secara otomatis memberikan respons.

2. Pendidik tidak dapat memaksakan kehendak kepada peserta didik.

3. Demokratisasi merupakan model pendidikan yang sangat relevan untuk pengembangan potensi dasar manusia, sekaligus 
membantu menanamkan sikap percaya diri dan tanggung jawab.

4. Proses pendidikan harus selalu mengacu pada sifat-sifat ketuhanan atau tauhid (theo-centris).

Terkait dengan manusia sebagai homo educabile, perlu ditekankan di sini bahwa firman Allah yang pertama kali diturunkan justru menegaskan karakter homo educabile ini melalui proses membaca. Sebagaimana firmannya dal Al-Qur`an Surat al-`Alaq ayat 1-5 yang artinya, " Bacalah dengan (menyebut) nama Tuhanmu Yang menciptakan, Dia telah menciptakan manusia dari segumpal darah. Bacalah, dan Tuhanmulah Yang Maha Pemurah, Yang mengajar (manusia) dengan perantaraan kalam. Dia mengajarkan kepada manusia apa yang tidak diketahuinya". Proses belajar ini telah dilakukan oleh Nabi Adam, ketika Allah mengajarkan kepadanya nama-nama segalanya. Lantas ibarat gayung bersambut, manusia pun merespon proses belajar ini dengan mengajar, sebagaimana firman Allah, “Dan (ingatlah) ketika Luqman berkata kepada anaknya, di waktu ia memberikan pelajaran kepadanya: 'Hai anakku, janganlah kamu mempersekutukan Allah, sesungguhnya mempersekutukan (Allah) adalah benar-benar kezhaliman yang besar".

Ketiga, manusia sebagai hamba Allah ('abd Allah) yang mulia. Kemuliaan manusia dibanding dengan makhluk lainnya adalah karena manusia dikaruniai akal untuk berpikir dan menimbang baik-buruk, banar-salah, terpuji-tercela, sedangkan makhluk lain semisal binatang, tumbuhan, mineral bahkan jin, tidaklah memperoleh kelebihan akal pikiran tersebut. Selain itu, bantuk kejadian manusia adalah yang paling baik. Allah berfirman, "sesungguhnya Kami telah menciptakan manusia dalam bentuk yang sebaik-baiknya". Juga firman Allah, "dan sesungguhnya telah Kami muliakan anak-anak Adam, Kami angkut mereka di daratan dan di lautan, Kmai beri mereka rezki dari yang baik-baik dan Kami lebihkan mereka dengan kelebihan yang sempurna atas kebanyakan makhluk yang telah Kami ciptakan".

Kelebihan dan kemuliaan manusia tersebut tidak bersifat abadi, tergantung pada sikap dan perbuatannya. Nabi bersabda: " Sesungguhnya Allah tidak melihat bentuk tampilan dan tubuh manusia, melainkan sesungguhnya Allah melihat amal perbuatan dan hati manusia". Manusia beramal shaleh dan berakhlak al-karimah, memiliki 


\section{Indah Aminatuz Zuhriyah - Misi Emansipatoris ...}

tempat mulia di sisi Allah dan manusia yang lain. Sebaliknya, manusia yang berbuat kerusakan dan berakhlak al-madzmumah, maka predikat kemuliannya turun ke tingkat yang paling rendah, bahkan lebih rendah dari hewan ternak. Karunia kemuliaan berupa akal, hati dan panca inderanya tidak dipergunakan semestinya.

Di samping kelebihan, manusia pun memiliki aspek kelemahan, misalnya kikir, paling banyak membantah, penuh keluh kesah, melampaui batas, tergesa-gesa, memiliki hawa nafsu yang mengajak pada kejahatan, mudah putus asa dan tidak berterima kasih, serta lainnya. Sebagai hamba Allah, manusia memikul tanggung jawab pribadi, orang yang berdosa tidak akan memikul dosa orang lain, dan pada hari kiamat nanti manusia akan datang kepada Allah dengan sendiri-sendiri. Ini membuktikan bahwa manusia sebagai hamba Allah itu memiliki kebebasan individual atas dirinya sendiri namun tetap bertanggung jawab atas segala perbuatannya. Diriwayatkan oleh Ibnu Umar r.a.:

Diriwayatkan daripada Nabi SAW. katanya, Baginda telah bersabda: "Kamu semua adalah pemimpin dan kamu semua akan bertanggung jawab terhadap apa yang kamu pimpin. Seorang pemerintah pemerintah adalah pemimpin manusia dan dia akan bertanggung jawab terhadap rakyatnya. Seorang suami adalah pemimpin bagi ahli keluarganya dan dia akan bertanggungjawab terhadap mereka. Manakala seorang isteri adalah pemimpin rumah tangga, suami dan anak-anaknya, dia akan bertanggungjawab terhadap mereka. Seorang hamba adalah penjaga harta tuannya dan dia juga akan bertanggungjawab terhadap jagaannya. Ingatlah, kamu semua adalah pemimpin dan akan bertanggungjawab terhadap apa yang kamu pimpin".

Fungsi manusia sebagai pemimpin inilah yang mengarahkan tugas kehadiran manusia di bumi sebagai khalifah.

Keempat, manusia sebagai khalifah fi al-ardl atau pemimpin, penguasa, pengganti, wakil dan pengelola di bumi, dalam arti lebih luas sebagai pemakmur alam semesta. Allah telah mengangkat manusia sebagai khalifah, bahkan para malaikat diperintahkan untuk sujud sebagai tanda penghormatan kepada manusia tersebut. Perintah sujud 
ini diulang dalam al-Qur`an hingga di enam surat, yakni al-Kahfi, alA 'raf, Thaha, Isra', al-Hijr dan Shaad. Iblis yang menolak bersujud telah dikutuk dan dikeluarkan dari surga. Sikap tidak mau sujud menghormat kepada khalifah ini merupakan pelanggaran terhadap perintah Allah, karena pada awalnya pengertian sujud adalah beribadah kepada Allah.

Dalam ayat yang lain, penyebutan khalifah tidak hanya dinisbatkan kepada Nabi Adam saja, melainkan juga beberapa Nabi yang lain, seperti Nabi Ibrahim dan Nabi Nuh. Bahkan tidak dikhususkan untuk pihak lelaki semata. Oleh karenanya, dengan berakhirnya misi kenabian dan nabi yang terakhir, yakni Nabi Muhammad SAW, juga telah tiada, maka manusia yang hidup pada generasi berikutnya yang akan meneruskan fungsi kekhalifahan di muka bumi. Hal ini berlaku umum, siapa saja yang memiliki kualifikasi dan kompetensi yang layak menjalankan amanat manusia sebagai pemimpin dan pemakmur maka dialah sebagai khalifah.

Dalam Al-qur`an, kata khalifah kadang kala disebut dalam bentuk jamak (plural), ynag berarti para khalifah. Implikasinya, pemimpin dan pemakmur bumi ini tidaklah hanya dimonopoli oleh orang per orang atau kelompok tertentu, melainkan bisa dilakukan oleh secara kolektif. Fungsi kekhalifahan mengharuskan empat sisi yang saling berkaitan; 1 ) pemberi tugas, dalam hal ini adalah Allah SWT.; 2) penerima tugas, dalam hal ini manusia, perorangan maupun kelompok; 3) tempat atau lingkungan di mana manusia berada; dan 4) materi penugasan yang harus dilaksanakan. Allah Berfirman:

“Dan Dialah yang menjadikan kamu penguasa-penguasa di bumi dan Dia meninggikan sebagian kamu atas sebagian (yang lain) beberapa derajat, untuk mengujimu tentang apa yang diberikan-Nya kepadamu. Sesungguhnya Tuhanmu amat cepat siksaan-Nya dan sesungguhnya Dia Maha Pengampun lagi Maha Penyayang".

Sebagai khalifah, manusia muslim dimaksudkan agar tampil dengan wajah yang ramah dan anggun untuk memimpin, mengelola dan memakmurkan bumi. Bukan sebaliknya sebagai orang yang tertindas, dan terbelakang dari berbagai kemajuan. Untuk mencapai yang demikian itu, pendidikan Islam diharapkan mampu memberdayakan fungsi khalifah dalam langkah-langkah yang konkrit. 


\section{Indah Aminatuz Zuhriyah - Misi Emansipatoris ...}

Bila hal tersebut tidak dilakukan, maka fungsi khalifah tadi dapat diambilaih oleh manusia dan golongannya yang lain. Dalam konteks ini, dapat dikatakan bahwa sekolah-sekolah Islam yang unggul amat kondusif untuk mewujudkan idealitas manusia sebagai khalifah ini.

Kelima, manusialahir dalamkeadaan fithrah. Fithrah berartipotensi yang dimiliki manusia untuk menerima agama, iman dan tauhid serta perilaku suci. Dalam pertumbuhannya, manusia sendirilah yang harus beupaya mengarahkan fithrah tersebut pada iman atau tauhid melalui faktor pendidikan, pergaulan dan lingkungan yang kondusif. Bila beberapa faktor tadi gagal menumbuhkan fithrah manusia, maka dikatakan bahwa fithrah tersebut dalam keadaan tertutup, yang dapat dibuka kembali bila faktor-faktor tadi mendukungnya. Sebagai wujud dalam bentuk potensi, fithrah dengan sendirinya memerlukan aktualisasi atau pengembangan lebih lanjut. Tanpa aktualisasi, fithrah dapat tertutupi oleh 'polusi' yang dapat membuat manusia berpaling dari kebenaran. Meski setiap orang memiliki kecenderungan ini, namun potensi ini tidak serta merta secara aktual mewujud dalam kenyataan. Karena itu, fithrah bersifat yazid wa yanqush atau bisa tambah bisa juga kurang. Bisabertambah, apabila ada faktor pembinaan dan pendidikan yang kondusif, dan bisa berkurang apabila ada faktorfaktor negatif yang mempengaruhinya.

Ibn al-Qayyim berpendapat bahwa manusia menerima Islam itu sama dengan jalan yang ditempuh seorang anak kecil yang menerima ibunya. Menurut pandangan ini, manusia bukanlah sudah muslim semenjak lahirnya, melainkan telah dibekali dengan potensi yang memungkinkannya menjadi muslim. Jadi, inti fithrah adalah bahwa manusia memiliki kecenderungan beragama, lebih spesifik lagi adalah Islam, iman dan tauhid.

Konsep fithrah tidaklah identik dengan teori tabula rasa, sama seperti halnya pandangan Islam Tentang manusia tidaklah identik dengan aliran dualisme maupun convergency. Teori tabula rasa, sebagaimana sebagaimana dikemukakan oleh John Locke, memandang bahwa manusia itu putih bersih, ibarat kertas belum dicoret. Lingkungan dan pendidikanlah yang mencoret kertas yang putih bersih tadi. Teori tabula rasa dengan demikian memandang manusia terlahir dalam keadaan pasif. Sebaliknya, fithrah memandang manusia lebih dari sekedar kertas putih dan bersih, melainkan dalam 
fithrah terdapat potensi yang terbawa oleh manusia, yakni daya atau kekuatan untuk menerima agama atau tauhid. Bedanya dengan teori tabula rasa, potensi ini bersifat dinamis. Lingkungan dan pendidikan diakui sebagai penyebab berkurang atau bertambahnya potensi fithrah manusia.

Lingkunganadalah faktoryang dapat mempengaruhi tingkahlaku manusia, namun bukan satu-satunya faktor. Di samping lingkungan, faktor lainnya adalah pendidikan. Diriwayatkan dari Abu Hurairah r.a. katanya: Rasulullah SAW. bersabda, "setiap anak dilahirkan dalam keadaan fithrah (yaitu suci bersih). Kedua orang tuanyalah yang membuatnya menjadi Yahudi, Nasrani, atau Majusi. Sebagaimana seekor ternak yang melahirkan anaknya (dengan sempurna kejadian dan anggotanya), adakah kamu menganggap hidung, telinga dan lain-lain anggotanya terpotong". Hadits ini menegaskan keterkaitan antara fithrah dan pendidikan.

Dengan demikian konsep fithrah ini memberi keseimbangan terhadap teori-teori yang lain. Teori bad-active, misalnya, memandang bahwa manusia terlahir dengan potensi berbuat jahat. Lingkungan dan pendidikanlah yang bertugas meluruskan potensi berbuat jahat tersebut. Bagi penganut Kristiani, implikasi teori ini nampak dalam keyakinannya bahwa manusia terlahir dengan membawa dosa warisan yang diturunkan oleh Adam. Lalu, untuk menebus dan memutus rangkaian dosa warisan tersebut, Nabi Isa hadir dengan kesediannya untuk disalib. Agaknya, teori ini aliran nativisme dalam hal kemampuan belajar anak. Teori good-active berpandangan sebaliknya. Sama dengan teori tabula rasa, teori good-active menilai bahwa manusia lahir dalam keadaan baik dan bersih, dan yang menyebabkan manusia tetap dalam keadaan baik dan bersih atau malah buruk dan kotor adalah lingkungan dan pendidikan yang dialami oleh anak. Maka dalam proses belajar teori ini dekat dengan aliran empirisme. Teori naturalactive mencoba untuk memadukan kedua teori sebelumnya dalam bentuk convergency. Bila kerangka pikir ketiga teori tersebut diikuti, ketiga teori di atas gagal untuk menjelaskan fenomena pengakuan Fir'aun terhadap Tuhan ketika ia akan tenggelam, maupun isteri Fir`aun yang justru beriman kepada Allah di tengah lingkungan yang anti-tauhid. Kasus Fir'aun dan isterinya yang "aneh" ini hanya bisa dijelaskan melalui konsep fithrah. 


\section{Indah Aminatuz Zuhriyah - Misi Emansipatoris ...}

Di samping dimensi spiritual fithrah sebagai kecenderungan untuk menerima agama dan bertauhid, maka dalam Islam, fithrah juga meliputi dimensi fisik-material bahkan sosial. Diriwayatkan dari Abu Hurairah r.a. katanya, NabiSAW telah bersabda, "Fithrah itu ada lima" atau juga diriwayatkan "ada lima perkara yang dikategorikan sebagai sifat fithrah seseorang manusia, yaitu berkhitan mencukur bulu kemaluan, memotong kuku, mencabut bulu ketiak dan menggunting kumis". Konsep fithrah berdimensi sosial terlihat dalam perintah untuk mengeluarkan zakat fithrah bagi setiap muslim. Diriwayatkan dari Ibnu Umar r.a. katanya, Rasulullah SAW telah mewajibkan zakat fithrah pada setiap bulan ramadhan kepada umat Islam, yaitu sebanyak satu shaa' yaitu satu gantang kurma atau satu shaa' (gantang) gandum. Kewajiban itu dikenakan kepada keseluruhan orang-orang Islam, merdeka ataupun hamba, lelaki ataupun wanita". Batas akhir penyaluran zakat fithrah adalah sebelum ditunaikannya shalah ied al-fithri. Diriwayatkan dari Ibnu Umar r.a. katanya, Rasulullah SAW memerintahkan agar zakat fithrah ditunaikan sebelum orang ramai keluar untuk mendirikan sembahyang hari raya".

Dari sseluruh uraiain tentang manusia dalam perspektif pendidikan Islam di atas dapat disimpulkan bahwa identitas manusia muslim secara sempurna (insan kamil atau muslim kaffah) diperoleh setelah fungsinya sebagai makhluk, pendidik dan terdidik, hamba Allah ('abd Allah), khalifah fi al-ardl, dan fithrah, serta karakteristik lainnya benar-benar dilakukan secara simultan dan seimbang dalam kesatuan yang utuh. Penekanan pada salah satunya sembari meninggalkan yang lain berakibat tidak sempurnanya identitas manusia sebagai insan kamil atau muslim kaffah. Bila pendidikan Islam hanya ditekankan pembentukan pribadi muslim dengan kesalehan individual atau ukhrawi-oriented, maka umat Islam pasti tertinggal jauh dalam kamajuan ilmu dan teknologi. Begitu pula halnya, bila peran pendidikan Islam hanya difokuskan pembentukan khalifah yang duniawi-oriented, sanggup menguasai ilmu dan teknologi dan menguak rahasia alam untuk dikelola demi kemakmuran hidup di dunia, tanpa memberi keseimbangan terhadap fungsinya sebagai 'abd Allah dan fithrahnya, maka manusia bisa saja pandai, tetapi jiwa dan hatinya kosong dari cahaya Ilahi. Semua fungsi manusi tersebut sebagai makhluk, pendidik dan si terdidik, 'abd Allah, khalifah fi alardl, dan fithrah - harus dioptimalkan dalam proses pendidikan Islam 
untuk mencapai insan kamil atau muslim kaffah.

\section{Menuju Emansipatorisme Dalam Pendidikan Islam}

MenurutRahim(2001:4-5) pendidikan merupakan term terpenting dan menentukan dalam perubahan masyarakat. Bahkan Islam sendiri menempatkan pendidikan dalam posisi vital. Bukan sebuah kebetulan jika dalam lima ayat pertama dimulai dengan perintah membaca. Tak heran jika dalam syiar yang dikembangkan nabi Muhammad dilakukan dengan pendekatan pendidikan.

Gagasan utama pendidikan, termasuk pendidikan Islam, terletak pada pandangan bahwa setiap manusia mempunyai nilai positif tentang kecerdasan, daya kreatif, dan keluhuran budi. Namun fokusnya bukan semata kemampuan ritual dan keyakinan tauhid tetapi juga akhlak sosial dan kemanusiaan. Kualitas akhlak pun tak bisa dicapai hanya dengan doktrin halal-haram, tapi usaha budaya dari rumah, masyarakat dan ruang kelas (Mulkhan, 2001: 17).

Tuhan yang merupakan fokus tertinggi dari kehidupan beragama tetap dipahami menjadi basic dalam segala bentuk kehidupan. Ia semestinyadimaknaisebagaibagianuniversalyangbersifattransenden. Ia merupakan titik esoteris (batiniyah) yang dimiliki masing-masing agama, biarpun dalam sisi eksoteris Tuhan memberikan pesan-pesan untuk kelompok-kelompok yang berbeda. Namun mesti dipahami pula, bahwa pesan-pesan Tuhan yang disampaikan dalam perbedaan dimensi ruang dan waktu tersebut mempunyai kesamaan dalam term besar; iman kepada sesuatu yang transenden (Tuhan) dan menjaga sisi-sisi kemanusiaan sebagai bagian dari urusan agama.

Sementara itu realitas menunjukkan keadaan masyarakat yang ditentukan oleh paradigma-paradigma dalam kehidupan pendidikan mereka. Dalam peta idiologi Giroux, sebagaimana dikutip Mansur Fakih (dalam O'Neil, 2001: xiii-xvi) ada tiga paradigma yang berpengaruh dalam dunia pendidikan. Pertama, paradigma konservatif. Pemahaman yang dipakai dalam paradigma ini menganut pada satu ketentuan sejarah (takdir). Fenomena dipahami sebagai satu keharusan yang tidak dapat diganggu gugat. Dalam bentuknya yang klasik terdapat keyakinan bahwa masyarakat tidak tidak bisa merencanakan perubahan atau mempengaruhi perubahan sosial, hanya Tuhan yang dapat melakukan menentukan perubahan. Namun 


\section{Indah Aminatuz Zuhriyah - Misi Emansipatoris ...}

pada masa selanjutnya, paradigma ini lebih menekankan pada pelestarian tradisi serta kebudayaan yang ada, tanpa mengurangi, mengkritik, memperbaiki, apalagi merubah. Lebih jauh, pemahaman tentang keadaan seseorang (nasib) lebih diakibatkan oleh kesalahan dirinya sendiri: miskin karena tidak bekerja, bodoh karena tidak belajar, dan lain sebagainya.

Kedua, paradigma liberal. Di tingkat ini, pemahaman tentang fenomena sosial termasuk perubahan yang ada di dalamnya lebih dikarenakan usaha-usaha yang dilakukan manusia. Secara individu yang kemudian akan menciptakan satu tatanan baru yang penuh kompetisi sehingga dinamis dalam masyarakat. Karenanya dalam salah satu aliran liberalisme, sructural fungsionalism, pendidikan lebih diutamakan sebagai penstabilan norma dan nilai masyarakat. Namun pendidikan di tingkat ini masih dianggap a-politis. Artinya, pendidikan tidak digunakan sebagai upaya untuk membangun satu tatanan masyarakat secara struktur global. Dalam pandangannya Excellence (keunggulan) adalah hal utama dalam pendidikan bukan yang lain. Sehingga tidak heran, jika dalam dimensi ini prestasi individu sangat lekat dan ditekankan, termasuk pembekalan secara individu untuk mengangkat derajat material (material oriented dalam pendidikan). Maka, jika nanti ada satu orang atau kelompok yang merasa terdeskriminasi atau kalah bersaing, itu adalah kesalahannya sendiri.

Ketiga, paradigma kritis. Pendidikan dalam paradigma ini dipahami sebagai arena perjuangan politik. Artinya, struktur masyarakat dalam sebuah negara dapat diatur dan diubah melalui pendidikan. Atau dengan kata lain, pendidikan adalah sebagai alat politik. Tujuan yang hendak dicapai oleh aliran ini adalah menghendaki adanya ruang kritis secara bebas terhadap struktur sosial dan ekonomi yang ada dalam masyarakat. Dalam perspektif kritis, pendidikan diarahkan untuk mengurusi tindakan kritis terhadap the dominant idiology, menuju transformasi sosial.

Penggunaan paradigma ketiga inilah yang menjadi pijakan dasar dalam melakukan perubahan. Kesadaran bahwa realitas sosial tidak terbentuk secara tiba-tiba tetapi akibat dari sebuah skenario dari penguasa. Kebijakan-kebijakan yang dibuat lembaga negara sebagai manifenstasi penguasa wilayah seringkali dibuat demi kepentingan 
penguasa bukan diorientasikan pada rakyat.

Paradigma tersebut menjadikan sistem pendidikan yang berlangsung selma ini memiliki kecenderungan menjauhkan manusia dari fithrahnya, yaitu untuk menjadi merdeka dan sadar akan pilihanpilihan hidupnya, bahkan sebaliknya malah mengasingkan mereka dari realitas yang ada disekelilingnya. Siswa lebih dianggap sebagai objek pendidikan, yang karenanya harus mau dijejali dengan semua hafalan dan informasi yang diberikan oleh gurunya tanpa diberikan kesempatan untuk bisa berpendapat sendiri, apalagi melakukan pemaknaan-pemaknaan, bahwa belajar seharusnya merupakan proses yang integral dan maknawi. Artinya, pendidikan/sekolah tidak seharusnya memisahkan siswa dari sejarahnya, lingkungan dimana ia hidup. Realitas (kenyataan) merupakan suatu proses sejarah yang dialektis dan bukannya berupa benda-benda atau abstraksi belaka.

Di samping itu, paradigma di atas juga sangat merugikan bagi lembaga pendidikan Islam. Menurut Qomar (2007: 24-27) selain secara ekonomi siswa/mahasiswa dalam lembaga pendidikan Islam berada dalam kategori kelas menengah ke bawah, secara intelektual potensi mereka juga lemah. Rata-rata siswa/mahasiswa mendaftar di berbagai lembaga pendidikan Islam karena merasa tidak mungkin diterima di lembaga pendidikan umum yang maju dan treutama yang berstatus negeri. Sebagian dari mereka yang telah gagal masuk di lembaga pendidikan umum negeri kemudian memilih lembaga pendidikan Islam. Dengan demikian, lembaga pendidikan Islam menjadi tempat pelarian siswa/mahasiswa yang gagal masuk lembaga pendidikan umum negeri, atau karena menyadari kemampuannya rendah dan mungkin amat rendah sehingga sengaja tidak pernah mendaftar di lembaga pendidikan umum negeri.

Keadaan ini menunjukkan adanya unsur keterpaksaan; daripada tidak sekolah/kuliah masih lebih baik memasuki lembaga pendidikan Islam. Kalaulah bukan keterpaksaan, setidaknya lembaga pendidikan Islam tetap bukan pilihan utama bagi siswa/mahasiswa. Kondisi psikologis ini tentunya tidak dapat memberikan pengaruh positif untuk membangkitkan gairah belajar guna mengejar penguasaan pengetahuan, baik yang difasilitasi lembaga maupun atas inisiatif sendiri.

Pada bagian lain, lembaga pendidikan Islam tidak mampu melakukan seleksi penerimaan siswa atau mahasiswa baru secara ketat dan 


\section{Indah Aminatuz Zuhriyah - Misi Emansipatoris ...}

kompetitif. Karena selisih antara kuota yang direncanakan dengan jumlah calon siswa atau mahasiswa yang mendaftar tidak berbeda banyak. Bahkan, tidak jarang jumlah siswa/mahasiswa pendaftar lebih sedikit daripada kuota yang direncanakan sehingga tidak ada persaingan sama sekali. Keadaan ini membuat pimpinan lembaga pendidikan Islam berada dalam posisi yang serba sulit (dilema). Jika tidak ada seleksi, berarti siswa/mahasiswa yang diterima bisa jadi berasal dari kalangan rendah secara intelektual. Akan tetapi, jika diseleksi secara ketat, hanya diperoleh siswa/mahasiswa dalam jumlah sedikit, yang akan menimbulkan masalah untuk meningkatkan potensi keuangan lembaga.

Kondisi potensi intelektual siswa/mahasiswa yang cukup parah ini kemudian diperburuk dengan banyaknya beban mata pelajaran/ mata kuliah,. Beban yang dihadapi siswa madrasah lebih berat dari siswa sekolah umum karena pelajarannya ditambah dengan rumpun mata pelajaran agama (al-Qur`an, hadits, akidah akhlak, tarikh, dan bahasa Arab). Demikian juga yang dialami oleh mahasiswa perguruan tinggi Islam, beban mereka lebih berat daripada mahasiswa perguruan tinggi umum.

Kenyataan yang serba memberatkan ini - potensi intelektual siswa/mahasiswa yang begitu lemah di satu sisi, dan beban pelajaran/ perkuliahan yang lebih berat pada sisi lain - dirasakan oleh pimpinan beserta jajaran staf pengajar pada lembaga pendidikan Islam sebagai tugs berat, bahkan "maha berat" yang terpaksa harus diemban. Sementara itu standar mutu lulusan yang dituntu dari lembaga pendidikan Islam sangat tinggi. Keadaan ini benar-benar timpang. Tidak ada keseimbangan antara cita-cita yang ingin diraih, beban, dan modal kemampuan yang dimiliki peserta didik. Pimpinan lembaga di mana pun tentu juga merasakan kesulitan jika menghadapi kondisi seperti ini.

Kondisi ini sangat berbeda dengan lembaga pendidikan umum negeri. Siswa/mahasiswa yang memasuki lembaga tersebut berasal dari kalangan garis depan (siswa/mahasiswa yang mencapai ranking papan atas) di sekolah asalnya. Semakin maju suatu sekolah atau perguruan tinggi, semakin ketat seleksi bagi siswa/mahasiswa yang akan diterima. Sampai hari ini, belum ada keberanian lembaga pendidikan yang maju untuk menerima siswa/mahasiswa yang kemampuannya rendah sebagai kelas percobaan, satu kelas saja misalnya. Kemudia, 
mereka digembleng dengan guru/dosen yang profesional, sarana prasarana yang lengkap, strategi pembelajaran yang bagus, dan situasi pembelajaran yang menggairahkan untuk mewujudkan perubahan pada siswa/mahasiswa tersebut. Sekolah/perguruan tinggi yang maju cenderung hanya memilih siswa/mahasiswa yang istimewa, yang tentu saja kemudian menjadi lulusan yang baik. Inilah model pendidkan kapitalis yang harus menghadapi pertanyaan yang sangat mendasar: apakah mutu lulusan yang dihasilkan dengan baik itu lantaran rekayasa lembaga tersebut, atau justru lantaran potensi sebelumnya yang memang sudah pandai?

Oleh karena itu, dengan mempertimbangkan potensi siswa/mahasiswa lembaga pendidikan Islam yang lemah, sementara tuntutan pelajaran/perkuliahannya lebih berat daripada siswa/mahasiswa lembaga pendidikan umum, maka perlu segera diusahakan model pendidikan emansipatoris. Yaitu, pendidikan yang berusaha mengubah secara signifikan kemampuan siswa/mahasiswa yang lemah menjadi siswa/mahasiswa yang pandai dan mampu bersaing dengan siswa/mahasiswa dari lembaga lainnya. inilah model pendidikan yang sejati karena mampu membawa perubahan positif, konstruktif, bahkan progresif.

\section{Prinsip Dasar Emansipatoris Dalam Pendidikan Islam}

Heteroginitas dan pluralitas manusia adalah sebuah rahmat Allah SWT yang perlu disyukuri oleh setiap manusia yang mukallaf. Semua yang tereksistensi adalah sebuah kenikmatan yang sangat luar biasa, yang secara langsung menyuruh manusia untuk mentafakuri segala realitas yang terwujud. Kelahiran Islam adalah untuk melakukan emansipasi dan liberasi terhadap kebodohan yang membelenggu manusia. Gerakan humanisasi oleh Nabi membangun pondasi yang kokoh untuk memanusiakan manusia.

Mengembalikan manusia pada essensinya sebagai makhluk rasional yang mempunyai aturan hukum, sebagai makhluk universal. Dengan eskatologis principle Nabi membangun sebuah formasi sosial berlandaskan the right and justice dimana semua manusia adalah sama tanpa membedakan status gender, sosial, etnik, bangsa, maupun bahasa. Yang membedakanya adalah ukuran kemuliaan disisi Tuhan yang maha Esa yaitu prestasi dan kualitas tanpa membedakan gender maupun etnik ( $49 ; 13)$. 


\section{Indah Aminatuz Zuhriyah - Misi Emansipatoris ...}

Emansipatoris adalah revolusi prioritas yang di hembuskan oleh sang Rasul, untuk membebaskan manusia dari mata rantai ekspolitasi karena hegemoni kekuasaan suatu kelompok, baik gender dan etnik. Islam memposisikan manusia dalam formasi yang sama mempunyai peran, hak dan kewajiban yang sama, yang membedakannya adalah kualitas dan kuantitas peranannya dalam membentuk formasi sosial.

Kata emansipasi berasal dari bahasa latin emancipatio yang berarti "pembebasan dari sebuah kekuasaan", (kamus popular). Dengan demikian bisa di deskripsi bahwa emansipasi adalah sebuah gerakan pembebasan dari seorang atau kelompok yang ter-ternegasikan dan termarginal-kan, dari hegemoni maupun dominasi kelompok yang berkuasa. Gerakan emansipasi timbul karena menginginkan adanya sebuah revolusi dari sebuah kondisi yang imperialis kearah liberalis, dari sentralistik ke desentralistik. Gerakan emansipasi berakar dari sebuah kelompok poletar yang termarginalkan yang menghendaki sebuah pengakuan terhadap eksistensinya.

Islam dan emansipatoris mempunyai sebuah close relation, yang satu merupakan identitas yang lainnya, begitupun sebaliknya, emansipasi adalah gerakan revolusi Islam itu sendiri. "Islam adalah agama yang menganut tentang egalitarian dan human equality bahwa pluralitas manusia adalah rahmat Tuhan, bukan merupakan sebuah pembeda derajat suatu kelompok etnik ataupun gender, semua adalah sama, yang membedakannya adalah kualitas dedikasinya terhadap dalam membentuk kesalehan individu dan social $(49 ; 13)$ ".

Misi kenabian Muhammad membawa sebuah a big change dalam peradaban manusia, sebuah revolusi terjadi dalam sejarah peradaban manusia, ketika orientasi hidup manusia berubah secara drastis, peralihan dari masa era kegelapan (dzulumat) ke masa era pencerahan (Annur).

Dengan demikian Islam emansipatoris adalah, gerakan liberasi dan emansipasi dimana manusia tidak bisa tunduk manusia lain, selain kepada kebenaran Tuhan dan manusiapun harus menolak berbagai bentuk ketidakadilan dan hanya untuk menerima dan memperjuangkan kebenaran dan keadilan.

Ketidak-adilan terutama eksploitasi dan penindasan manusia selalu terjadi disepanjang sejarah manusia, begitupun sampai saat ini, hal tersebut tidak bisa lepas dari tabiat manusia yang bersifat prudensial. 
Saat ini negasi suatu kelompok terhadap kelompok lain masih terjadi, bahkan merambat sampai kedalam berbagai sendi-sendi kehidupan manusia, baik dalam kehidupan politik, social, budaya bahkan agama sekalipun.

Rasisme, borjoisme-poletarisme, feodalisme-coolisme, kastaisme adalah cerita sejarah manusia yang selalu membeda-bedakan kelas dengan status sosial gender dan etnik. Yang paling mencuat sampai saat ini adalah masalah kapitalisme dan rasisme yang cukup meracuni peradaban manusia saat ini. Egoisme kaum putih (white ethnic) atas kaum hitam (black ethnic) masih saja terjadi seperti dalam dunia sepakbola kasus rasisme sering jadi tontonan biasa. Hal yang mungkin paling mewabah adalah kapitalisme, baik ekonomi, pendidikan maupun politis. Kapitalisme melahirkan ketidakadilan sosial sehingga muncullah monopoli, elitisme, individualisme, borjoisme dan berbagai istilah yang mendiskreditkan suatu kelompok manusia tertentu. Globalisasi telah membuat keberhasilan manusia dan sekaligus mencemari peradabannya itu sendiri. Ketidak pedulian sosial dari kaum intelektual, hartawan dan penguasa menjadikan sebuah ketidakadilan sosial.

Islam mengajarkan sebuah pluralitas sosial bahwa manusia tercipta secara heterogen dan hal itu bukan merupakan sebuah pembeda derajat dan martabat manusia. Tapi merupakan sebuah kelebihan masing-masing, meskipun memiliki kebebasan tapi tidak untuk saling mendiskreditkan dan menegasikan tapi untuk sharing-take and give. Islam tidak memandang perbedaan suku, bangsa maupun kelompok sosial tertentu, sehingga Islam itu sangat menghargai adanya hak asasi manusia (al'Haqq-al-Syakhsiyah) yang digemborkan oleh barat, tapi dengan catatan hal itu tidak melampui batas aturan transendensi.

Untuk itu Dawam (2003: 104-105) memberikan kerangkan orientasi pendidikan pluralisme atau pendidikan multikultural agar pendidikan tersebut tidak kehilangan arah dan dibangun berdasarkan orientasi nilai dasar multikulturalisme, yaitu:

Pertama, orientasi kemanusiaan. Kemanusiaan atau humanisme merupakan sebuah nilai kodrati yang menjadi landasan sekaligus tujuan pendidikan. Kemanusiaan bersifat universal, global, di atas semua suku, aliran, ras, golongan, dan agama. Dengan demikian institusi pendidikan yang dibangun pun tidak bersifat eksploitatif, 


\section{Indah Aminatuz Zuhriyah - Misi Emansipatoris ...}

mendominasi, kompetisi sebebas-bebasnya. Orientasi yang demikian memunculkan manusia yang humanis tanpa kehilangan jati dirinya.

Kedua, orientasi kebersamaan. Kebersamaan atau kooperativisme merupakan sebuah nilai yang sangat mulia dalam masyarakat yang plural dan heterogen. Kebersamaan yang dibangun adalah kebersamaan yang sama sekali lepas dari unsur kolutif maupun koruptif. Ke_ bersamaan yang dibangun adalah kebersamaan yang tidak merugikan diri sendiri, orang lain, lingkungan, negara, bahkan Tuhannya. Dengan demikian diharapkan muncul manusia yang aktif, kreatif, toleran, tenggang rasa yang mendalam, dan terbuka.

Ketiga, orientasi kesejahteraan. Kesejahteraan yang dimaksud disini adalah kondisi sosial yang menjadi harapan semua orang. Konsistensi terhadap kesejahteraan harus dibuktikan dengan perilaku menuju terciptanya kesejahteraan. Kesejahtraan yang dimaksud bukan terjebak dalam pemenuhan kebutuhan materi yang berlebih dan sama banyaknya oleh semua orang. Melainkan yang menjadi orientasi adalah bahwa masyarakat secara sadar dan tidak dipaksa mengatakan bahwa dirinya telah sejahtera, dengan terpenuhinya kebutuhan-kebutuhan dasar, dihargai, dan diakui oleh orang lain. Konsekwensi yang kemudian terjadi adalah adanya kedamaian dimana semua orang merasa aman, dihargai, diakui, dan diperlakukan sebagai manusia oleh semua pihak yang berinteraksi secara langsung atau tidak langsung.

Keempat, orientasi proporsional. Proporsional merupakan sebuah nilai yang dipandang dari aspek apapun adalah sangat tepat. Tepat landasan, tepat proses, tepat pelaku, tepat ruang, tepat waktu, tepat anggaran, tepat kualitatif, tepat kuantitatif, dan tepat tujuan. Ketepatan disini tidak diartikan sebagai ketepatan yang bersifat rigid dalam arti hanya menggunakan salah satu pertimbangan, misalnya pertimbangan kualitas intelektual, atau kuantitasnya, melainkan ketepatan yang ditinjau dari semua sudut pandang, khususnya yang ersifat langsung dengan nilai proporsional. Orientasi pendidikan inilah yang diharapkan menjadi pilar pendidikan multikultural.

Kelima, orientasi mengakui pluralitas dan heterogenitas. Pluralitas dan heterogenitas merupakan sebuah kenyataan yang tidak mungkin ditindas secara fasih dengan memunculkan sikap faatisme terhadap sebuah kebenaran yang diyakini oleh sekelompok orang.

Keenam, orientasi anti hegemoni dan anti dominasi. Dominasi dan 
hegemoni adalah dua istilah yang sangat populer bagi kaum tertindas. Istilah ini dihindari jauh-jauh oleh para pengikut faham liberalis, kapitalis, globalis, dan neoliberalis. Hegemoni yang dimaksud adalh hegemoni dalam segalanya; politik, pelayanan dan lain sebagainya.

Berdasarkan penjelasan di atas, pendidikan yang merupakan tonggak perubahan masyarakat, semestinya mesti diawali dengan reparadigmatisasi menuju pemberdayaan rakyat. Pluralisme, pembebasan, kritisisme, keadilan mestilah dijadikan landasan dalm pergerakannya. Mengubah masyarakat yang telah 'sakau' dengan modernitas bukan tugas yang mudah dan cepat. Tetapi butuh sense of social construction yang memadai di samping waktu yang cukup lama. Dan ini merupakan tugas seluruh generasi bangsa.

Dengan demikian, emansipatorisme Islam pada dasarnya pengakuan terhadap kebebasan (liberasi) tetapi tidak lepas dari sebuah aturan sosial. Emansipatorisme Islam adalah pengakuan terhadap persamaan (egalitarian), Persaudaraan universal (universal brotherhood), kesetaraan (equality), keadilan sosial (social justice) dan keadilan ekonomi (economical justice) semua konsep tersebut adalah untuk membangun sebuah formasi sosial yang yang berkonsep civil society.

\section{E. Penutup}

Arus globalisasi dan modernitas telah menimbulkan implikasi dan kompleksitas yang demikian mendalam. Budaya, ekonomi, ilmu pengetahuan, tekhnologi, politik dan lain sebagainya hampir semua berkiblat pada Barat, sebagai representasi kemajuan peradaban. Sedangkan Timur, sangat kesulitan untuk sekedar sejajar apalagi mengungguli Barat. Dan ia hanya mempunyai tiga pilihan: mengekor Barat tanpa kreativitas dan menjadi 'jajahan' mereka; menolak dan melawan dengan radikal hingga secara konyol menjadi negara 'tersingkir'; atau mencoba mengikuti arus global tetapi tetap berusaha bangkit dengan perubahan-perubahan paradigmatik sebagai modal awal.

Pendidikan dianggap mempunyai peranan penting dalam proses transformasi sosial. Namun pendidikan ini semestinya harus dibebaskan dari hegemoni wacana yang dikembangkan oleh penguasa. Penguasa disini bukan hanya negara tetapi ruang yang lebih luas dalam tataran global. yaitu kapitalisme dan segala bentuk penindasannya. Harapannya, tercipta satu tatanan masyarakat yang adil dan 
Indah Aminatuz Zuhriyah - Misi Emansipatoris ...

sejahtera lepas dari segala bentuk penindasan serta kritis dan punya sumber daya manusia yang memadai.

Hal ini bukan menjadi tugas yang mudah. Karenanya gerakan menuju transformasi sosial seharusnya dilakukan oleh semua pihak, terutama generasi bangsa yang dianggap masih memegang idealisme, cita-cita luhur dan semangat yang berapi-api.

\section{F. Daftar Pustaka}

Abdurrahman, Muhammad. 2003. Pendidikan di Alaf Baru: Rekonstruksi atas Moralitas Pendidikan. Yogyakarta: Primasophie.

Anonim. 2006. Undang-Undang Republik Indonesia Nomor 20 Tahun 2003 Tentang Sistem Pendidikan Nasional. Bandung: Citra Umbara.

Assegaf, Abd. Rahman. 2004. Pendidikan Tanpa Kekerasan: Tipologi Kondisi, Kasus dan Konsepsi. Yagyakarta: Tiara Wacana Yogya.

Dawam, Ainurrofiq, A. 2003. Emoh Sekolah; Menolak Komersialisasi Pendidikan dan Kenibalisme Intelektual Menuju Pendidikan Multikultural, Yogyakarta: Inspeal Ahimsakarya Press.

Fadjar, Malik. 1995. Pergumulan Pemikiran Pendidikan Tinggi Islam. Malang: Bestari UMM

Mulkhan, Abdul Munir. 2001. Humanisasi Pendidikan Islam, dalam Hamami Zada, et. Al., Jurnal Tashwirul Afkar edisi no. 11.

Mustafied, et. al. 2001. Pendidikan Kritis Transformatif, Jakarta: PB PMII.

O'Neil, William F. 2001. Educational Idiologies, terj. Omi Intan Naomi (Idiologi-idiologi Pendidikan), Yogyakarta: Pustaka Pelajar.

Qomar, Mujamil. 2007. Manajemen Pendidikan Islam: Strategi Baru Pengelolaan Lembaga Pendidikan Islam. Jakarta: Penerbit Erlangga.

Rahim, Husni, 2001. Arah Baru Pendidikan Islam di Indonesia, Jakarta: Logos. 